\title{
KAJIAN PEMOTONGAN BABIRUSA (Babyrousa babirussa celebensis DENIGER) SEBAGAI SATWA ENDEMIK SULAWESI UTARA PADA BEBERAPA PASAR TRADISIONAL DI KABUPATEN MINAHASA
}

\author{
H.J. Kiroh, F.S. Ratulangi, S.C. Rimbing dan I. Wahyuni
}

Fakultas Peternakan Universitas Sam Ratulangi Manado, 95115.

\begin{abstract}
ABSTRAK
Babirusa (Babyrousa babyrussa celebensis D.) merupakan plasma nutfah yang tiada terhingga nilainya meskipun sudah hampir 60 tahun sebagai satwa yang dilindungi, tetapi status babirusa tetap saja dinyatakan dalam keadaan genting (endangered). Permasalahannya perburuan satwa ini masih terjadi bahkan pada pasarpasar tradisional di Kabupaten Minahasa masih memperdagangkan daging babirusa. Tujuan penelitian ini untuk menkaji ada tidaknya pemotongan dan penjualan daging babi rusa pada beberapa pasar tradisional di Kabupaten Minahasa.Metode penelitian yang digunakan adalah metode survey dengan objek penelitian adalah penangkap, penjual dan pembeli daging babirusa pada pasar-pasar tradisional di Kabupaten Minahasa. Hasil penelitian menunjukkan bahwa daging babirusa masih beredar diperdagangkan pada beberapa pasar tradisional di Kabupaten Minahasa. Hasil penelitian menunjukkan sekitar $0-25 \%$ sebagai pemburu/penangkap, 8,33 - 50\% sebagai penampung/penjual dan 58,33 $100 \%$ sebagai pembeli/konsumen tetap daging babi rusa yang tersebar pada pasar tradisional Tondano, Remboken, Kawangkoan, Langowan dan Tanawangko. Dari hasil penelitian ini dapat disimpulkan bahwa pemotongan dan perdagangan daging babirusa sebagai satwa yang dilindungi masih diperjualbelikan pada pasar-pasar tradisional di Kabupaten Minahasa.
\end{abstract}

*Kosepondensi (corresponding author)

Email: hengkijohanis.26@gmail.com
Kata kunci: Babirusa, satwa endemik, pasar tradisional

\section{ABSTRACT}

STUDY ON SLAUGHTER ACTIVITY OF BABIRUSA (Babyrousa babirussa celebensis DENIGER) AS THE ENDEMIC FAUNA IN NORTH SULAWESI AT THE SEVERAL TRADITIONAL MARKETS IN MINAHASA REGENCY. Babirusa (Babyrousa babyrussa celebensis D.) is categorized as a valuable germinal plasma and included into protected fauna since sixty years along a go. Therefore, this animal was noted into endangered animals. However, the hunting activities of the local community are occurring in the remote area of Minahasa as indicated by availability of meat trading of this animal. The objective of this study was to evaluate the slaughter activities dealing with meat trading of this endemic fauna on several traditional markets in Minahasa regency. Study was conducted by survey method focusing on hunters, traders and consumers buying meat of this animal on several traditional markets in Minahasa regency. Results showed that meat of Babirusa (Babyrousa babyrussa celebensis D.) were still traded and found on several traditional markets in Minahasa regency indicated by hunter existences of 0 to 25 percents, meat sellers of 8.33 to 50 percents, and fixed meat consumers of 58.33 to 100 percents of this animal. These cases were spreading on the traditional markets around districts of Tondano, Remboken, Kawangkoan, Langowan and Tanawangko. As the conclusion that 
slaughters and trading activities of the protected Babirusa (Babyrousa babyrussa celebensis D.) were existing recently in the remote areas of Minahasa Regency.

Key words: Babirusa (Babyrousa babyrussa celebensis D.), endemic, traditional market.

\section{PENDAHULUAN}

Indonesia merupakan Negara dengan tingkat keanekaragaman hayati yang sangat tinggi, ditandai dengan ekosistem, jenis dalam ekosistem dan plasma nutfah (genetik) yang berada di dalam setiap jenisnya (Abdullah et al., 2015).

Pulau Sulawesi memiliki kekhasan dalam keanekaragaman jenis satwa yang tidak terdapat ditempat lain. Pulau Sulawesi memiliki 127 jenis satwa yang terdiri dari satwa yang menyusui $79(62 \%)$ jenis endemik, 328 jenis burung dan 81 (25\%) jenis endemik, 29 jenis amphibi dan 19 (66\%) jenis endemik dan 38 jenis kupukupu ekor sriti besar (29\%) jenis endemik. Salah satu dari $62 \%$ jenis endemik yang ada di Sulawesi yaitu Babirusa (Babyrusa babyrussa) (Anwarhadi et al., 2018) Sedangkan menurut (Adnyane et al., 2010; Sutherland- Smith, 2015) bahwa Babirusa merupakan satu-satunya jenis hewan yang digolongkan ke dalam jenis Babyrousa dibawah family Suidae. Hal ini tidak jauh berbeda (Houston et al., 2001; MacDonald,
2005) menyatakan bahwa babirusa sering ditempatkan pada sub familinya yaitu Babyrusinae dan keluarga terdekatnya di yakini adalah babi-babi Eropa yang sudah punah sekitar 35 juta tahun lalu. Menurut Patry et al. (1995) bahwa Babirusa biasanya hidup berkelompok terdiri 6-7 ekor dengan system sosial matrilineal yaitu induk betina merupakan pusat pergerakan kelompok sedangkan jantan dewasa cendrung untuk hidup sendiri-sendiri (soliter), kalaupun ditemukan berjalan bersama dengan pasangannya maka situasi tersebut hanya pada saat musim kawin.

Babirusa merupakan plasma nutfah yang tiada terhingga nilainya, meskipun sudah hampir 60 tahun sebagai satwa yang dilindungi, tetapi status babirusa tetap saja dinyatakan dalam keadaan genting (endangered). Hal ini merupakan suatu kenyataan yang sangat menyedihkan sebagai bukti kurangnya kepedulian dari berbagai pihak. Menurut IUCN (2012); Drury (2011) bahwa tanpa sistem hukum yang memadai untuk mencegah kepunahan keanekaragaman hayati, SDA hayati akan terus menurun hingga mengalami kepunahan sehingga menghilangkan nilai potensialnya. Untuk itu menurut Macdonald (2005), perlu upaya-upaya pelestarian atau kegiatan reintroduksi yang bertujuan agar suatu jenis dapat berkembang biak kembali di habitatnya semula. 
Populasi dua subspesies Babyrousa babyrussa Linnaeus di Pulau Sula dan Buru serta Babyrousa babyrussacelebensis Deniger di Pulau Sulawesi sampai saat ini belum pernah dilaporkan. Dikawatirkan pemanfaatan hutan secara lebih intensif untuk kepentingan manusia akan berdampak pada kerusakan habitat sehingga mempercepat laju kepunahannnya. Disamping adanya perburuan liar dari kelompok masyarakat dan mencermati kondisi di pasar-pasar tradisional yang ada di Minahasa seperti pasar Tondano, Kawangkoan dan Langowan dan pasar tradisional lainnya, disinyalir banyak memperdagangkan daging dari satwa-satwa endemik yang dilindungi. Membuktikan kebenaran tersebut, telah dilakukan penelitian untuk mengkaji seberapa jauh peredaran daging babirusa di pasar tradisional, dengan harapan hasil penelitian ini menjadi bahan rekomendasi bagi pemerintah yang ikut berperan dalam pelestarian babirusa di Sulawesi Utara.

\section{MATERI DAN METODE PENELITIAN}

Penelitian ini dilaksanakan pada pasar-pasar tradisional yang ada di Kabupaten Minahasa dengan metode survey. Obyek penelitian adalah para penangkap, penjual dan pembeli daging disetiap pasar tradisional yang merupakan responden primer dan juga data sekunder yang diperolehdari instansi-instansi terkait dengan penelitian ini. Data dikumpulkan di lapangan dengan mendatangi langsung responden (penangkap, penjual dan pembeli) dan mewawancarai dengan pertanyaan-pertanyaan yang telah dipersiapkan sebelumnya dalam bentuk quisioner. Data/informasi yang diperoleh ditabulasi dan dianalisa secara sederhana yaitu menghitung persentase dari tiap-tiap variabel yang terkait dengan responden penangkap, penjual dan pembeli.

\section{HASIL DAN PEMBAHASAN}

\section{Keberadaan Penangkap, Penjual dan Pembeli Daging Babirusa}

Hasil penelitian menunjukkan bahwa persentase responden sebagai penangkap, penjual dan pembeli daging babi rusa bervariasi pada beberapa pasar tradisional yang ada di Kabupaten Minahasa, seperti terlihat pada Tabel 1 . Dari data pada Tabel 1, dapat dilihat bahwa besaran masyarakat yang berprofesi sebagai pemburu/penangkap babi rusa sekitar $\quad 0 \% \quad-\quad 25 \%, \quad$ sebagai penampung/penjual daging babi rusa sekitar $8,33 \%$ - 50\%, dan sebagai pembeli/konsumen daging babi rusa sekitar 
Tabel 1. Persentase Responden Sebagai Penangkap, Penjual dan Pembeli Daging Babirusa pada Beberapa Pasar Tradisional di Kabupaten Minahasa

\begin{tabular}{llcccc}
\hline No & Pasar Tradisional & $\begin{array}{c}\text { Jumlah } \\
\text { Responden }\end{array}$ & $\begin{array}{c}\text { Pemburu/ } \\
\text { Penangkap }\end{array}$ & $\begin{array}{c}\text { Penampung/ } \\
\text { Penjual }\end{array}$ & $\begin{array}{c}\text { Pembeli/ } \\
\text { Konsumen }\end{array}$ \\
\hline 1 & Tondano & 12 & $2(16,66 \%)$ & $1(8,33 \%)$ & $12(100 \%)$ \\
2 & Remboken & 12 & $0(0 \%)$ & $1(8,33 \%)$ & $7(58,33 \%)$ \\
3 & Kawangkoan & 12 & $1(8,33 \%)$ & $3(25,00 \%)$ & $12(100 \%)$ \\
4 & Langowan & 12 & $3(25,00 \%)$ & $6(50,00 \%)$ & $12(100 \%)$ \\
5 & Tanawangko & 12 & $0(0 \%)$ & $1(8,33 \%)$ & $5(41,66 \%)$ \\
\hline Total & & 60 & $6(10,00 \%)$ & $12(20,00 \%)$ & $48(80 \%)$ \\
\hline
\end{tabular}

58,33 - 100\%. Hasil pengamatan di pasar tradisional Tondano pemburu/penangkap babirusa mencapai $16,66 \%$ dan pengumpul/penjual $\quad 8,330 \% \quad$ serta konsumen tetap mencapai $100 \%$. Selanjutnya di pasar tradisional Remboken tidak ada masyarakat yang berprofesi sebagai pemburu/penangkap babirusa dan $8,33 \%$ berprofesi sebagai pengumpul/penjual serta pembeli/konsumen tetap daging babirusa mencapai 58,33\%. Kemudian di pasar tradisional Kawangoan, masyarakat yang berprofesi sebagai pemburu/penangkap babirusa $8,33 \%$ dan penampung/penjual babirusa $8,33 \%$ dengan pembeli/konsumen tetap daging babirusa $25 \%$. Begitu pula di pasar tradisional Langowan dijumpai $25 \%$ masyarakat berprofesi sebagai pemburu/penangkap dan pengumpul/penjual $50 \%$ dengan pembeli/konsumen tetap daging babirusa mencapai 100\%, Pasar tradisional Tanawangko tidak ditemukan masyarakat yang berprofesi sebagai pemburu/penangkap, sedangkan penampung/penjual $8,33 \%$ dengan pembeli/konsumen tetap mencapai $41,66 \%$. Hasil penelitian ini menggambarkan bahwa cukup tingginya minat masyarakat di Minahasa mengkonsumsi daging babirusa, dan kalau kejadian ini terjadi secara terus menerus maka di kuatirkan populasi babirusa di Sulawesi Utara akan punah. Hal ini juga telah disampaikan oleh (MilnerGulland dan Cayton, 2002; Rosyidi dan Wibowo, 2020) bahwa kasus penurunan populasi babirusa di Sulawesi utara salah satunya disebabkan daging babirusa dijadikan makanan khas masyarakat lokal non muslim yang banyak di jual di pasarpasar tradisional, walaupun babirusa termasuk satwa yang dilindungi karena masuk taraf endangered, tetapi di beberapa pasar Sulawesi utara masih saja di temukan peredaran daging babirusa yang di jual secara bebas. Hasil wawancara juga dengan beberapa responden di pasar-pasar 
tradisional menyatakan bahwa penangkapan yang sering terjadi pada satwa-satwa liar adalah di saat mereka melakukan aktifitas hidupnya seperti aktifitas berkubangan. Hasil ini sesuai yang disampaikan oleh Pisalemo (2012); Tulung (2017) bahwa aktifitas berkubangan yang umumnya dilakukan oleh satwa liar seperti: babi, anoa, kerbau, nil (hippopotamus), gajah, babirusa, dan lain sebagainya yang tidak tahan terhadap panasnya suhu lingkungan. Hal ini dilakukan dengan tujuan mengontrol suhu tubuh agar tetap dalam zona nyaman (thermoneutral zona) sehingga terhindar dari cekaman panas (heat stress). Bervariasinya profesi yang dijalani masyarakat Kabupaten Minahasa salah satu faktor juga akibat permintaan daging babirusa yang kadang-kadang meningkat disaat adanya kegiatan hajatan keluarga, hari ulang tahun desa dan pengucapan syukur, serta di lain pihak disebabkan desakan ekonomi keluarga sehingga mendorong masyarakat di Kabupaten Minahasa beralih profesi dari petani menjadi pemburu/penangkap dan pengumpul/penjual hewan babirusa. Kondisi yang demikian akan semakin parah lagi bila tidak ada pihak-pihak baik pemerintah, LSM maupun institusi perguruan tinggi ikut peduli terhadap kelestarian hewan-hewan langkah endemik yang dilindungi agar kehidupan mereka lebih lestari dan menjadi Ikon pariwisata

daerah Sulawesi Utara, untuk itu perlu adanya suatu kolaborasi penelitian terhadap satwa-satwa liar endemik Sulawesi utara, karena menurut Agungpriyono et al. (2007); Leus (2000) bahwa sampai saat ini sistem pencernaan babirusa belum banyak diketahui, walaupun penelitian terhadap lambung, jenis makanan serta pola pakan babirusa yang di tangkarkan di kebun binatang sudah pernah dilakukan, oleh karena perlu terus dilakukan penelitian secara exsitu, yang tujuannya untuk memperkecil penangkapan satwa liar endemik di habitat aslinya, dan sekaligus dapat dijadikan pusat penelitian satwasatwa endemik dunia, pusat rekreasi dan pusat pelatihan/pendidikan satwa endemik Sulawesi Utara. Achmad et al. (2013) menyatakan bahwa sumber alam yang sangat menarik untuk di jadikan sebagai objek ekowisata salah satunya adalah satwa liar karena mempunyai peranan yang unik dalam ekosistem. Hasil penelitian yang diperoleh bahwa satwa-satwa liar seperti: Monyet hitam, babirusa, babihutan, belum tersentuh untuk dijadikan pengembangan ekowisata satwa endemik yang justru masyarakat desa bermukim disekitar hutan hanya menfaatkan satwa-satwa liar itu sebagai barang dagangan terutama penjualan daging satwa liar karena dianggap memiliki khasiat tersendiri. Hal ini juga yang menjadi permasalahan saat ini, yang menyebabkan menurunnya 
populasi babirusa di habitat alamnya karena faktor perburuan, predator dan penyakit. Pernyataan ini diperkuat oleh Siswiyanti (2011) yang menyatakan bahwa hal tersebut merupakan persoalan yang tampak dan bukan persoalan yang mendasar (underlying problem), untuk itu perlu penelitian mencari jalan keluar agar populasi babirusa akan tetap terjaga.
Jenis Daging Hewan yang Beredar pada Pasar Tradisional di Kabupaten Minahasa

Hasil penelitian di beberapa pasar tradisional Kabupaten Minahasa menunjukkan bahwa masih dijumpai peredaran daging hewan-hewan yang dilindungi namun setiap pasar sangat bervariasi peredarannya seperti yang terlihat pada Tabel 2.

Tabel 2. Jenis Daging yang Beredar pada Beberapa Pasar Tradisional di Kabupten Minahasa

\begin{tabular}{|c|c|c|c|c|}
\hline No & Pasar Tradisional & Ketersedian & Jenis Daging & $\begin{array}{c}\text { Jumlah } \\
\text { (ekor) }\end{array}$ \\
\hline \multirow{3}{*}{1} & \multirow{3}{*}{ Tondano } & Per Hari & $\begin{array}{l}\text { 1. Babi ras } \\
\text { 2. Babi hutan } \\
\text { 3. Anjing } \\
\text { 4. Ayam buras } \\
\text { 5. Broiler } \\
\text { 6. Bebek } \\
\text { 7. Tikus ekor putih }\end{array}$ & $\begin{array}{c}12 \\
4 \\
5 \\
15 \\
60 \\
10 \\
-\end{array}$ \\
\hline & & Per Minggu & $\begin{array}{l}\text { 1. Kelelawar } \\
\text { 2. Burung weris } \\
\text { 3. Burung puyuh }\end{array}$ & $\begin{array}{l}20 \\
40 \\
- \\
\end{array}$ \\
\hline & & Per Bulan & $\begin{array}{l}\text { 1. Babirusa } \\
\text { 2. Ular Patola } \\
\text { 3. Biawak } \\
\text { 4. Monyet }\end{array}$ & $\begin{array}{l}2 \\
1 \\
- \\
-\end{array}$ \\
\hline \multirow{3}{*}{2} & \multirow{3}{*}{ Remboken } & Per Hari & $\begin{array}{l}\text { 1. Babi ras } \\
\text { 2. Babi hutan } \\
\text { 3. Anjing } \\
\text { 4. Ayam buras } \\
\text { 5. Broiler }\end{array}$ & $\begin{array}{c}12 \\
4 \\
6 \\
10 \\
40\end{array}$ \\
\hline & & Per Minggu & $\begin{array}{l}\text { 1. Bebek } \\
\text { 2. Tikus ekor putih } \\
\text { 3. Kelelawar } \\
\text { 4. Burung weris } \\
\text { 5. Burung puyuh }\end{array}$ & $\begin{array}{l}20 \\
20 \\
15 \\
30 \\
-\end{array}$ \\
\hline & & Per Bulan & $\begin{array}{l}\text { 1. Babirusa } \\
\text { 2. Ular Patola } \\
\text { 3. Biawak } \\
\text { 4. Monyet }\end{array}$ & $\begin{array}{l}1 \\
1 \\
- \\
-\end{array}$ \\
\hline 3 & Kawangkoan & Per Hari & 1. Babi ras & 20 \\
\hline
\end{tabular}




\begin{tabular}{|c|c|c|c|c|}
\hline & & & $\begin{array}{l}\text { 2. Babi hutan } \\
\text { 3. Anjing } \\
\text { 4. Ayam buras } \\
\text { 5. Broiler } \\
\text { 6. Tikus ekor putih } \\
\text { 7. Kelelawar }\end{array}$ & $\begin{array}{l}15 \\
10 \\
25 \\
50 \\
40 \\
50\end{array}$ \\
\hline & & Per Minggu & $\begin{array}{ll}\text { 1. } & \text { Bebek } \\
\text { 2. } & \text { Burung Weris } \\
\text { 3. } & \text { Burung Puyuh }\end{array}$ & $\begin{array}{l}30 \\
50 \\
45\end{array}$ \\
\hline & & Per Bulan & $\begin{array}{l}\text { 1. Babirusa } \\
\text { 2. Ular Patola } \\
\text { 3. Biawak } \\
\text { 4. Monyet }\end{array}$ & $\begin{array}{l}3 \\
2 \\
- \\
-\end{array}$ \\
\hline 4. & Langowan & Per Hari & $\begin{array}{l}\text { 1. Babi ras } \\
\text { 2. Babi hutan } \\
\text { 3. Anjing } \\
\text { 4. Ayam buras } \\
\text { 5. Broiler } \\
\text { 6. Tikus ekor putih } \\
\text { 7. Kelelawar } \\
\text { 8. Bebek } \\
\text { 9. Burung puyuh } \\
\end{array}$ & $\begin{array}{l}25 \\
21 \\
15 \\
30 \\
40 \\
50 \\
65 \\
15 \\
-\end{array}$ \\
\hline & & Per Minggu & $\begin{array}{l}\text { 1. Burung weris } \\
\text { 2. Babirusa } \\
\text { 3. Ular Patola }\end{array}$ & $\begin{array}{c}40 \\
3 \\
1\end{array}$ \\
\hline & & Per Bulan & $\begin{array}{l}\text { 1. Biawak } \\
\text { 2. Monyet }\end{array}$ & $\begin{array}{l}2 \\
2\end{array}$ \\
\hline 5 & Tanawangko & Per Hari & $\begin{array}{l}\text { 1. Babi ras } \\
\text { 2. Babi hutan } \\
\text { 3. Anjing } \\
\text { 4. Ayam buras } \\
\text { 5. Broiler }\end{array}$ & $\begin{array}{c}15 \\
5 \\
4 \\
15 \\
22\end{array}$ \\
\hline & & Per Minggu & $\begin{array}{l}\text { 1. Tikus ekor putuh } \\
\text { 2. Kelelawar } \\
\text { 3. Bebek } \\
\text { 4. Burung weris } \\
\text { 5. Burung puyuh } \\
\end{array}$ & $\begin{array}{l}20 \\
15 \\
- \\
- \\
-\end{array}$ \\
\hline & & Per Bulan & $\begin{array}{l}\text { 1. Ular Patola } \\
\text { 2. Babirusa } \\
\text { 3. Monyet } \\
\text { 4. Penyu }\end{array}$ & $\begin{array}{l}1 \\
1 \\
- \\
2\end{array}$ \\
\hline
\end{tabular}

Hasil penelitian menunjukan bahwa adanya variasi perdagangan hewan liar/endemik yang dilindungi, masih dijumpai dan diperdagangkan di beberapa pasar tradisional, dimana aktivitas penjualan daging per hari tertinggi yaitu pasar Langowan diikuti pasar Kawangkoan, Tondano, Remboken dan Tanawangko. Hasil wawancara terhadap responden di semua pasar tradisional, pada awalnya 
mereka menolak memberikan informasi tentang perdagangan daging babirusa karena beranggapan tim peneliti merupakan polisi atau instansi yang mengadakan rasia penjualan daging babirusa. Setelah dilakukan pendekatan sambil memperkenalkan diri sebagai peneliti, baru kemudian ada penerimaan secara baik sambil dilakukan wawancara. Dari informasi penjual maupun konsumen khususnya di pasar tradisional bahwa mereka sangat hati-hati menjual daging babi rusa, karena menurut mereka jika ada rasia dari instansi berwewenang dan kedapatan menjual daging babirusa sanksinya sangat berat, berupa kurungan badan dan denda sebesar Rp. 500.000.000. Sehingga di pasar tradisional Langowan mereka menjual daging babirusa dengan sebutan kalumata. Jika pembeli/konsumen menanyakan secara terbuka ada jual daging babirusa maka para penjual saling memberikan informasi dengan berbagai kode khusus seperti bersiul, kedipan mata atau menggunakan bahasa daerah setempat bahwa ada aparat yang sedang melakukan rasia, sehingga timbul pertanyaan faktor apa yang menyebabkan maraknya perdagangan daging satwa liar di pasarpasar tradisional, dan hasil wawancara menunjukan kurangnya pemahaman konservasai hewan-hewan liar endemik Sulawesi utara dan masaalah ekonomi masyarakat yang bermukim disekitar hutan-hutan konservasi. Pendapat ini diperkuat oleh hasil penelitian beberapa peneliti seperti (Tulung et al., 2013; Tulung, 2017) bahwa faktor ekonomi penduduk disekitar lokasi atau habitat babirusa disinyalir merupakan akar permasalahan yang perlu dicari jalan keluarnya

Umumnya penjualan daging babirusa dilakukan secara sembunyisembunyi, dan biasanya penjual sudah mengenal pembeli/konsumen yang sudah menjadi langganan mereka. Sebagian konsumen beranggapan daging satwa liar punya khasiat tersendiri dalam hal ini akan menambah vitalitas, walaupun secara ilmiah perlu suatu pembuktian apakah kandungan nutrisi dari daging satwa liar endemik punya ciri khas tersendiri dan untuk itu perluh suatu kegiatan ilmiah yang lebih kongkrit sehingga tidak menyesatkan masyarakat yang senang mengkonsumsi daging tersebut. Hasil penelitian Reksowardojo (1995) menyatakan kandungan protein kasar daging babirusa mirip degan daging babi hutan atau lebih tinggi dari protein daging rusa timor. Dengan kata lain daging babirusa lebih unggul dibandingkan babi hutan maupun rusa timor ditinjau dari kandungan nutrisi dan tidak kala ditinjau dari aspek warna, kekenyalan, tekstur dan struktur daging. 
Sumber Pemasok Daging Babirusa pada Beberapa Pasar Tradisional Di Kabupaten Minahasa

Hasil penelitian menunjukkan bahwa daerah pemasok hewan babirusa di pasar-pasar tradisional Kabupaten Minahasa adalah Sulawesi Tengan dan Gorontalo serta Minahasa, namun orangorang yang ikut terlibat rata-rata berasal dari Kabupaten Minahasa. Besarnya persentase daerah/wilayah yang mengedarkan satwa babirusa dapat dilihat pada Gambar 1.

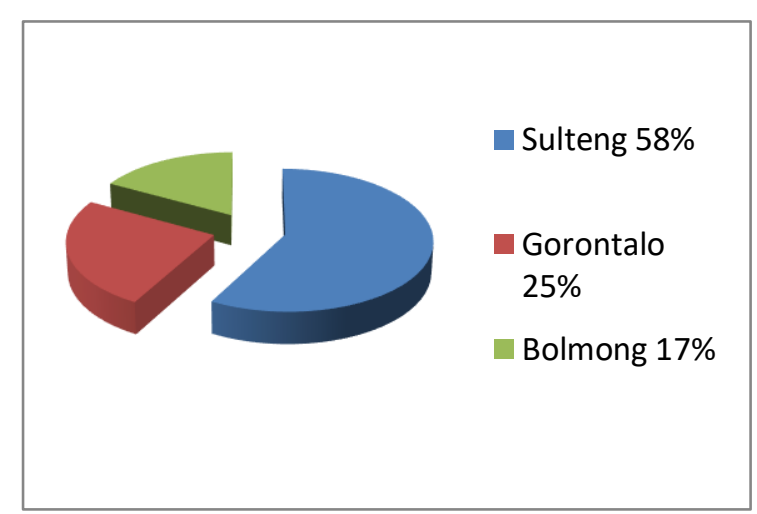

Gambar 1. Diagram Daerah Sumber Pemasok Daging Babirusa

Nilai persentase pemasok hewan babirusa pada pasar tradisional di Kabupaten Minahasa berasal dari Sulawesi Tengah mencapai 58\% diikuti Gorontalo $25 \%$ dan Bolmong 17\%. Hasil wawancara dengan para pedagang penangkap dan pengumpul maupun konsumen tetap, mereka mengatakan bahwa pasar daging babirusa dilakukan secara rapih agar tidak diketahui petugas, tetapi ada juga dari mereka yang tertangkap.Kalau dilihat dari daerah pemasok maka disarankan petugas baik dari kepolisian atau KSDA harus lebih waspada, karena sampai sekarang masih di jumpai daging satwa langkah endemik dan dilindungi beredar pada beberapa pasar tradisional di Kabupaten Minahasa. Bila langkah-langkah ini tidak diimplementasikan maka dikuatirkan jenisjenis satwa langkah endemik akan menurun populasinya dan pada akhirnya akan menjurus pada kepenuhan.

\section{KESIMPULAN}

Berdasar hasil penelitian dan pembahasan maka dapat ditarik kesimpulan sebagai berikut: Pemotongan dan perdagangan daging babirusa sebagai satwa yang dilindungi masih diperjualbelikan pada pasar-pasar tradisional di Kabupaten Minahasa.

\section{REKOMENDASI}

1. Perlu dilaksanakan sidak atau rahasia untuk menghentikan pemotongan dan penjualan daging babirusa oleh pemerintah melalui instansi terkaitpada pasar-pasar tradisional di Kabupaten Minahasa

2. Pelunya koordinasi antar pemerintah daerah untuk memutus mata rantai perdagangan daging babirusa 
3. Perlunya penyuluhan kepada masyarakat oleh instansi terkait tentang keberadaan hewan endemik babirusa, untuk dijaga dan dilestarikan.

\section{DAFTAR PUSTAKA}

Abdullah, M., M.P. Mamat, M.R. Yaacob, A. Radam, dan L.H. Fui. 2015. Estimate the conservation value of biodiversity in national heritage site: A case of Forest Research Institute Malaysia. Procedia Environmental Sciences 30: 180-185.

Achmad, A., P.O. Ngakan, A. Umar, dan A. Asrianny. 2013. Potensi Keanekaragaman Satwaliar Untuk Pengembangan Ekowisata Di Laboratorium Lapangan Konservasi Sumberdaya Hutan Dan Ekowisata Hutan Pendidikan Unhas. Jurnal Penelitian Kehutanan Wallacea 2(2): 79-92.

Adnyane, I.K.M., A.A. Macdonald, A. Winarno, dan S.A. Priyono. 2010. Studi mikro anantomi pankreas Babi Rusa (Baby Raousa Babi Russa) menggunakan metode pewarnaan baku dan imunohistokimia. Jurnal Kedokteran Hewan 4(2): 49-52

Agungpriyono, S., M. Kurohmaru, W.E. Prasetyaningtyas, L. Kaspe, K.Y.G. Leus, M. Sasaki, dan A.A. Macdonald. 2007. A lectin histochemical study on the testis of the babirusa, Babyroussa babyrussa (Suidae). Anatomia, histologia, embryologia 36(5): 343-348.
Anwarhadi, I.N., E. Labiro, I.N. Korja. 2018. Komposisi vegetasi habitat Babi Rusa (Baby Rousa Baby Russa) Di Kawasan Hutan Pendidikan Universitas Tadulako Kecamatan Bolano Lambunu Kabupaten Parigi Mountong. Jurnal Warta Rimba 6(4): 8-17

Drury, R. 2011. Hungry for success: urban consumer demand for wild animal products in Vietnam. Conservation and Society 9(3): 247-257

Houston, E. W., P.K. Hagberg, M.T. Fischer, M.E. Miller, dan C.S. Asa. 2001. Monitoring pregnancy in babirusa (Babyrousa babyrussa) with transabdominal

ultrasonography. Journal of Zoo and Wildlife Medicine, 32(3), 366-372

IUCN. 2012. The IUCN Red List Of Threatened $\quad$ Spesies. 2012. https://WWW.Iucnredlist.Org/details 15953. Diakses tanggal 24 Maret 2014

Leus, K. 2000. Feeding babirusa (Babyrousa babyrussa) in captivity.. Filander Verlag Furth, PP: 27-250

Macdonal, A. A. 2005. The Conservation Of The Babi Rusa (Baby Rousa Baby Russa) In: N. Sugiri, A. H. Mustari, I. S. Suwelo Dan Djuwita (Eds). Kumpulan Makalah Seminar Sehari Peduli Anoa Dan Babi Rusa Indonesia, PP 90-111. Institut Pertanian Bogor.

Milner-Gulland, E. J. dan L. Clayton. 2002. The trade in babirusas and wild pigs in North Sulawesi, Indonesia. Ecological

Economics 42(1-2): 165-183.

Rosyidy, M. K. dan A. Wibowo. 2020. GISBased spatial model for habitat 
suitability of Babirusa (Babyrousa celebensis), in Gorontalo Province. Jurnal Geografi Lingkungan Tropik 4(1)

Patry, M., K. Leus, dan A.A. Macdonald. 1995. Group structure and behaviour of babirusa (Babyrousa babyrussa) in Northern Sulawesi. Australian Journal of Zoology 43(6): 643-655.

Pisalemo. S. B. 2012. Deskripsi Kubangan Dan Interaksi Sosial Berkubangan Babi Rusa (Baby Rousa Celebensis Deninger) Di Suaka Marga Satwa Nantu Provinsi Gorontalo. Skripsi. Fakultas Peternakan Universitas Sam Ratulangi, Manado

Reksowardojo, D. J. 1995. Studi Kemampuan Produksi Babirusa (Babyrousa babyrussa celebensis Deninger ) Melalui Upaya Budidaya. Tesis. Program Pascasarjana IPB, Bogor.
Siswiyanti, J. 2011. Strategi Konservasi Babi Rusa Sulawesi (Baby Rousa Celebencis). Tesis. Sekolah Pasca Sarjana Institut Pertanian Bogor.

Sutherland-Smith, M. 2015. Suidae and Tayassuidae (Wild pigs, peccaries). Fowler's Zoo and Wild Animal Medicine, Volume 8: 568.

Tulung, B. 2017. Hewan Endemik Sulawesi Babirusa. Penerbit: Lembaga Pembinaan dan Pengembangan Pembelajaran, Universitas Sam Ratulangi, Manado

Tulung, B., J.F. Umboh, A.F. Pendong, dan D. Tambayong. 2013. Isolation and Characterization of Cytochrome B of Baby Roussa Babi Russa Celebencis. Genbank; Kc 540-871.1.NCBI-DNA and RNA-Nucleotide Database. https://www.ncbi.nlm.nih.gov/nucco $\mathrm{re} / \mathrm{kc} 540871.1$ 